\title{
Influence of nalidixic acid on tandem heterotrophic-autotrophic kinetics in a
} "NIPHO" activated sludge reactor

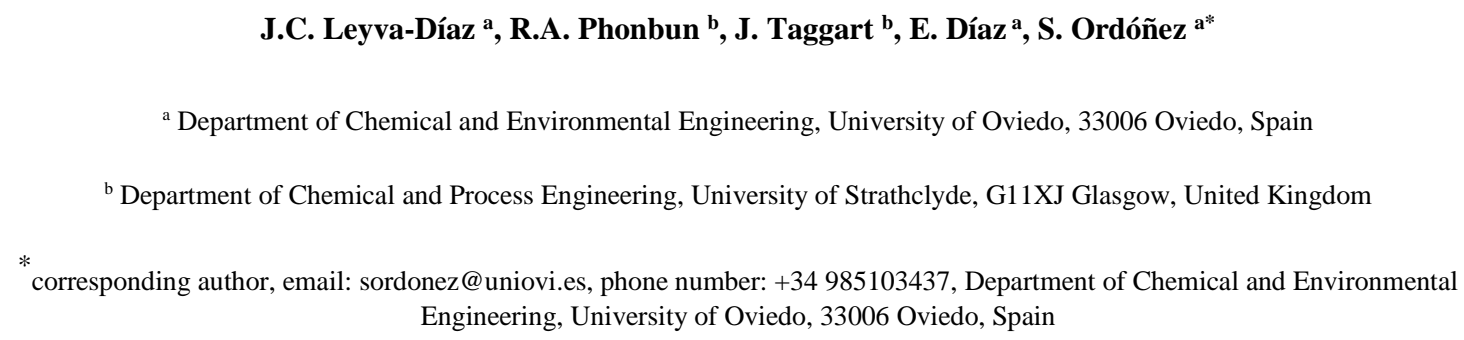

\section{ABSTRACT}

This work analyzes the effect of nalidixic acid (NAL) on the kinetics of the heterotrophic and autotrophic biomass growth within a "NIPHO" activated sludge reactor treating municipal wastewater. Thus, the effect of this chemical in the degradation rates of carbon and nitrogen sources and net biomass growth rate is evaluated. Activated sludge samples were taken at three different operation conditions, changing the values of hydraulic retention time $(2.8-3.8 \mathrm{~h})$, biomass concentration (1,400-1,700 $\left.\mathrm{mgVSS} \mathrm{L}^{-1}\right)$, temperature $\left(12.6-14.8^{\circ} \mathrm{C}\right)$, and sludge retention time (11.012.6 day). A respirometric method was applied to model the kinetic performance of heterotrophic and autotrophic biomass in absence and presence of NAL, and a multivariable statistical analysis was carried out to characterize the influence of the operation variables on the kinetic response of the system, which was finally optimized. The results showed that there was no inhibitory effect of NAL on heterotrophic biomass, with an increase of net heterotrophic biomass growth rate from 1.70 to 6.73 $\operatorname{mgVSS~L}{ }^{-1} \mathrm{~h}^{-1}$ at the most favorable period. By contrast, the autotrophic biomass was negatively affected by NAL, reducing the value of net autotrophic biomass growth rate from 25.37 to $10.29 \mathrm{mgVSS} \mathrm{L}^{-1} \mathrm{~h}^{-1}$ at the best operation conditions. In general, biomass concentration and temperature had the highest influence on the degradation rate of 
carbon and nitrogen sources, whereas hydraulic retention time and sludge retention time were the most influential on net heterotrophic and autotrophic biomass growth rates.

Keywords: Activated sludge reactor; Autotrophic biomass; Heterotrophic biomass; Kinetic modeling; Nalidixic acid; Respirometry.

\section{INTRODUCTION}

In the last years, pharmaceuticals have caused a growing concern due to their presence and environmental persistence. Among these compounds, it should be highlighted the antibiotics, which are used in human medicine, animal husbandry and agriculture (Tahrani et al., 2015; Lekunberri et al., 2017). Since last decade, global consumption and use of antibiotics raised from 50 to 70 billion standard units approximately (Gelbrand et al., 2015). As a consequence of their extensive application, antibiotic residues are continuously introduced into the environment through different ways, such as the effluents from wastewater treatment plants (WWTPs), surface runoff and soil leaching (Park and Choi, 2008; Servais and Passerat, 2009; Zhang et al., 2009, Mojica and Aga, 2011). In light of this, antibiotic contamination is recognized as an emerging environmental pollution in aquatic environments due to their potential adverse effects on the ecosystem and human health (Huang et al., 2001; Kummerer, 2009; Yang et al., 2011). In particular, despite the fact that antibiotics have toxic effects, the main problem related to the presence of lot of these compounds in the environment is the development of antibiotic-resistant microorganisms, which is the real problem affecting human health.

Among the most widely used antibiotics worldwide, nalidixic acid (NAL), a quinolonederived antibiotic with molecular formula $\mathrm{C}_{12} \mathrm{H}_{12} \mathrm{~N}_{2} \mathrm{O}_{3}$ (1-ethyl-7-methyl-4-oxo-[1,8]- 
naphthyridine-3-carboxylic acid), is causing a major concern due to its release to the environment and frequent presence in surface water and wastewater (Sirtori et al., 2011). Pollice et al. (2012) worked with wastewater containing a NAL concentration of $48 \mathrm{mg} \mathrm{L}^{-1}$ in an integrated membrane bioreactor-ozonation system, and Laera et al. (2012) studied different technologies based on membrane bioreactor with diverse oxidation stepts to treat raw wastewater with a NAL concentration of $50 \mathrm{mg} \mathrm{L}^{-1}$. NAL could affect human health through the immune system due to its toxicity and carcinogenicity effects (Patiño et al., 2016; Ibrahim et al., 2002). In this regard, the oral $\mathrm{LD}_{50}$ of NAL is $2,040 \mathrm{mg} \mathrm{kg}^{-1}$ in rats, and the potential for bioaccumulation has a value of $\log K_{\text {Ow }}$ (n-octanol/water) of 1.59 .

In this work, an improved wastewater treatment process called "NIPHO" activated sludge reactor was studied. This technology combines anaerobic, anoxic and aerobic zones within the bioreactor in order to remove nitrogen and phosphorus, as well as carbonaceous compounds, from wastewater (Kim et al., 2013; Leyva-Díaz et al., 2016). This technology requires lower cost, energy and environmental footprint than other technologies for biological nitrogen and phosphorus removal (Park et al., 2010; Lai et al., 2011; Liu et al., 2013). Furthermore, this system has the advantage of stable capacity of simultaneous nutrient removal (Abu-Alhail and Lu, 2014).

Most of current WWTPs were not designed for the abatement of antibiotics. Thus, when wastewater containing antibiotics enters the bioreactor of a wastewater treatment plant (WWTP), they can impact microbial communities of the activated sludge, affecting the biodegradation processes of carbonaceous, nitrogenous or phosphorous compounds (Kümmerer, 2013). To the best of our knowledge, the effect of NAL on the kinetic behavior of heterotrophic and autotrophic biomass in systems based on activated sludge technology has not been reported yet, with very few studies analyzing the influence of 
emerging pollutants on microbial kinetics, particularly autotrophic kinetics, of biological systems for municipal wastewater treatment (Calero-Díaz et al., 2017; LeyvaDíaz et al., 2017a).

In this regard, respirometric method has been used to carry out the kinetic modeling for NIPHO activated sludge system because of its high accuracy and reproducibility (Leyva-Díaz et al., 2013). As a consequence, this will provide further understanding of the influence of NAL on the processes of organic matter and nitrogen removal, which could lead to improved operation of NIPHO activated sludge reactor.

The main objective of this study is to analyze the effect of NAL on the heterotrophic and autotrophic biomass of a NIPHO activated sludge bioreactor through the assessment of its kinetic modeling by a respirometric method. This allows to simulate the possible influence of an intrusion of NAL on the heterotrophic and autotrophic microorganisms within the bioreactor and to assess their adaptive capacity through possible modifications in the rates of substrate degradation and net biomass growth. In addition, different mathematical models were developed for the heterotrophic and autotrophic kinetic performance in order to optimize the operational variables, i.e. hydraulic retention time (HRT), biomass concentration as mixed liquor volatile suspended solids $\left(\mathrm{X}_{\mathrm{VSS}}\right)$, temperature $(\mathrm{T})$ and sludge retention time (SRT).

\section{MATERIALS AND METHODS}

\subsection{Description of the NIPHO activated sludge reactor}

WWTP of Villapérez is located in the Nora River Basin Sanitation System in the Central Area of Asturias (Spain) and receives wastewater from the surrounding municipalities, including the city of Oviedo. The process line at this plant includes 
pretreatment, primary settling, biological treatment, secondary settling and tertiary treatment for purification.

102

103

The biological treatment is carried out through a NIPHO activated sludge reactor, which is fed with municipal wastewater coming from the outlet of the primary settler (Fig. 1). The bioreactor is divided into six zones, i.e. one pre-anoxic zone, one anaerobic zone, two anoxic zones, one facultative zone and one aerobic zone to facilitate the biological nutrient removal (BNR) process. The facultative zone can operate as an oxic or anoxic zone. The aerobic zone provides the optimal conditions for organic substrate removal, nitrification and phosphate assimilation. Internal mixed liquor recirculation consists of a nitrate recirculation from the outlet of the bioreactor to the anoxic zone. The external recirculation is done from the secondary settler to the pre-anoxic zone of the bioreactor to minimize the effect of nitrate in wastewater entering the anaerobic zone, whereas an external recycling is necessary to maintain the working mixed liquor suspended solids (MLSS) concentration inside the bioreactor.

\subsection{Operational conditions and activated sludge samples}

Activated sludge samples were taken at three different periods, in which the main operation parameters were different: HRT (2.8-3.8 h), $\mathrm{XVSS}_{\mathrm{VS}}\left(1,400-1,700 \mathrm{mgVSS} \mathrm{L}^{-1}\right), \mathrm{T}$ (12.6-14.8 $\left.{ }^{\circ} \mathrm{C}\right)$ and SRT (11.0-12.6 day). Table S1 shows the values of these variables for the different periods.

Activated sludge samples (each respirometric test requires $2 \mathrm{~L}$ of mixed liquor) were collected from the aerobic zone of the NIPHO activated sludge reactor during the steady state of the three operation periods. The different samples of activated sludge were preconditioned by aerating them for $18 \mathrm{~h}$ at $20^{\circ} \mathrm{C}$ of temperature to achieve endogenous 

conditions in which any kind of substrate contained in the sample is consumed (LeyvaDíaz et al., 2013).

\subsection{Kinetic study}

127 After pre-conditioning the sample of activated sludge, one liter of this sample was transferred to the bioreactor of the experimental set-up to carry out the exogenous respirometric assays for heterotrophic and autotrophic biomass in absence of NAL (Fig. S1a). This type of respirometric test was performed by using, firstly, sodium acetate and, subsequently, ammonium chloride under a continuous aeration supplied by an air pump. The bioreactor worked at temperature of $20.0 \pm 0.1^{\circ} \mathrm{C}$ and stirring rate of $500 \mathrm{rpm}$ to homogenize the mixed liquor. Since $\mathrm{pH}$ in the bioreactor was stable throughout the experiments $(7.40 \pm 0.30), \mathrm{pH}$ control was not necessary. After this respiration test, the endogenous respirometric assay was carried out by leaving without aeration the mixed liquor.

In parallel, both kinds of respiration tests were applied to the remaining liter of sample of activated sludge in presence of NAL. These experiments were initiated when the basis line of DO was accomplished after the addition of NAL solution to get a concentration of $50 \mathrm{mg} \mathrm{L}^{-1}$. The stock solution of NAL was prepared as indicated in Text S1 in the Supplementary Material.

The time course of dissolved oxygen (DO), due to the consumption of substrate sources by the microorganisms, was measured by the oximeter $\mathrm{XS}$, OXY70, with optical $\mathrm{O}_{2}$ electrode LDO70. The LDO70 probe uses luminescence optical technology for DO measurements in the mixed liquor samples. The oximeter OXY70 has an USB connector for exporting data to PC and DataLink 70 Software. 
147 The dynamic oxygen uptake rate $\left(\mathrm{R}_{\mathrm{S}}, \mathrm{mgO}_{2} \mathrm{~L}^{-1} \mathrm{~h}^{-1}\right)$ was obtained through the derivation

148 of DO depending on the time for the exogenous respirometric experiments (Leyva-Díaz 149 et al., 2017b). In a similar way, the static oxygen uptake rate (OUR, $\left.\mathrm{mgO}_{2} \mathrm{~L}^{-1} \mathrm{~h}^{-1}\right)$ was 150 calculated through the derivation of DO as a function of the time for the endogenous 151 respiration tests.

\subsubsection{Estimation of kinetic parameters}

The kinetic performance for heterotrophic and autotrophic biomass within the NIPHO activated sludge reactor was evaluated under the influence of shock additions of NAL for each one of the three stationary periods of operation.

The exogenous respirometric tests included two experiments. The first one was based on the use of sodium acetate at increasing concentrations $(50,80$ and $100 \%$ of $500 \mathrm{mg}$ $\mathrm{L}^{-1}$ stock solution) to determine the kinetic parameters for heterotrophic biomass. Having finished this experiment, the second one is carried out through three additions of ammonium chloride at increasing concentrations $\left(50,80\right.$ and $100 \%$ of $150 \mathrm{mg} \mathrm{L}^{-1}$ stock solution) to evaluate the kinetic parameters for autotrophic biomass. The preparation of both stock solutions is described in Text S1 in the Supplementary Material. In light of this, when the basis line of DO was achieved, the dynamic oxygen uptake rate for heterotrophic biomass $\left(\mathrm{R}_{\mathrm{S}, \mathrm{H}}\right)$ was monitored for the additions of carbon source within the operation periods 1, 2 and 3 (Fig. S2). Once the basis line of DO was reestablished, the dynamic oxygen uptake rate for autotrophic biomass $\left(\mathrm{R}_{\mathrm{S}, \mathrm{A}}\right)$ was registered for the additions of ammonium source in the different operation periods (Fig. S3). The concentrations of heterotrophic and autotrophic biomass, $\mathrm{X}_{\mathrm{H}}\left(\mathrm{mgVSS} \mathrm{L}^{-1}\right)$ and $\mathrm{X}_{\mathrm{A}}$ (mgVSS L $\mathrm{L}^{-1}$ ), respectively, were calculated by applying the heterotrophic and autotrophic fractions to mixed liquor volatile suspended solids (MLVSS) (Metcalf, 2003), which was evaluated from MLSS (APHA, 2012). In this regard, the 
172 heterotrophic fractions were $92.51 \%, 92.58 \%$ and $95.47 \%$ for the periods 1,2 and 3 , 173 respectively; and the autotrophic fractions resulted in $7.49 \%, 7.42 \%$ and $4.53 \%$ for the 174 operation periods 1,2 and 3 , respectively.

175 Regarding the endogenous respirometric test, the evolution of OUR is shown in Fig. S4 176 for the three operation periods.

177 In this way, the exogenous respirometric tests for heterotrophic biomass allowed to 178 evaluate the yield coefficient in absence and presence of NAL ( $\mathrm{Y}_{\mathrm{H}, \mathrm{n} / \mathrm{NAL}}$ and $\mathrm{Y}_{\mathrm{H}, \mathrm{NAL}}$, 179 respectively), the maximum specific growth rate in absence and presence of NAL $180\left(\mu_{\mathrm{m}, \mathrm{H}, \mathrm{n} / \mathrm{NAL}}\right.$ and $\mu_{\mathrm{m}, \mathrm{H}, \mathrm{NAL}}$, respectively) and the half-saturation coefficient for carbon 181 source in absence and presence of NAL ( $\mathrm{K}_{\mathrm{M}, \mathrm{n} / \mathrm{NAL}}$ and $\mathrm{K}_{\mathrm{M}, \mathrm{NAL}}$, respectively). This kind 182 of experiments for autotrophic biomass provided the assessment of the yield coefficient 183 in absence and presence of $\mathrm{NAL}\left(\mathrm{Y}_{\mathrm{A}, \mathrm{n} / \mathrm{NAL}}\right.$ and $\mathrm{Y}_{\mathrm{A}, \mathrm{NAL}}$, respectively), the maximum specific growth rate in absence and presence of NAL $\left(\mu_{\mathrm{m}, \mathrm{A}, \mathrm{n} / \mathrm{NAL}}\right.$ and $\mu_{\mathrm{m}, \mathrm{A}, \mathrm{NAL}}$, respectively) and the half-saturation coefficient for ammonium source in absence and presence of NAL ( $\mathrm{K}_{\mathrm{NH}, \mathrm{n} / \mathrm{NAL}}$ and $\mathrm{K}_{\mathrm{NH}, \mathrm{NAL}}$, respectively). For its part, the endogenous 187 respiration test enabled the calculation of the decay coefficient for heterotrophic 188 biomass in absence and presence of NAL ( $\mathrm{b}_{\mathrm{H}, \mathrm{n} / \mathrm{NAL}}$ and $\left.\mathrm{b}_{\mathrm{H}, \mathrm{NAL}}\right)$ and for autotrophic biomass in absence and presence of NAL $\left(\mathrm{b}_{\mathrm{A}, \mathrm{n} / \mathrm{NAL}}\right.$ and $\left.\mathrm{b}_{\mathrm{A}, \mathrm{NAL}}\right)$.

Moreover, the degradation rate for carbon source in absence and presence of NAL $\left(\mathrm{r}_{\mathrm{su}, \mathrm{H}, \mathrm{n} / \mathrm{NAL}}\right.$ and $\mathrm{r}_{\mathrm{su}, \mathrm{H}, \mathrm{NAL}}$, respectively), the degradation rate for ammonium source in absence and presence of NAL ( $\mathrm{r}_{\mathrm{su}, \mathrm{A}, \mathrm{n} / \mathrm{NAL}}$ and $\mathrm{r}_{\mathrm{su}, \mathrm{A}, \mathrm{NAL}}$, respectively), the net 193 heterotrophic biomass growth rate in absence and presence of NAL $\left(\mathrm{r}^{\prime}{ }_{\mathrm{x}, \mathrm{H}, \mathrm{n} / \mathrm{NAL}}\right.$ and $194 \mathrm{r}_{\mathrm{x}, \mathrm{H}, \mathrm{NAL}}^{\prime}$, respectively) and the net autotrophic biomass growth rate in absence and 195 presence of NAL $\left(\mathrm{r}^{\prime}{ }_{\mathrm{X}, \mathrm{A}, \mathrm{n} / \mathrm{NAL}}\right.$ and $\mathrm{r}_{\mathrm{X}, \mathrm{A}, \mathrm{NAL}}$, respectively) were determined. 
The kinetic parameters for heterotrophic and autotrophic biomass, in absence and presence of NAL, were estimated as indicated in the nine steps described in Text S2 in the Supplementary Material (all equations are included in Table S2). Fig. S1b shows the assessment algorithm for kinetic modeling in absence and presence of NAL.

\subsubsection{Mathematical modeling and optimization}

201

In this research, HRT, $\mathrm{XVSS}_{\mathrm{VS}}, \mathrm{T}$ and SRT were the independent operational variables. Four models were proposed for the kinetic parameters, i.e. yield coefficient (Y), maximum specific growth rate $\left(\mu_{\mathrm{m}}\right)$, half-saturation coefficient for substrate source $\left(\mathrm{K}_{\mathrm{S}}\right)$ and decay coefficient (b), to evaluate the heterotrophic and autotrophic kinetics in absence and presence of NAL. This proposal was based on the mass balances applied to the bioreactor and the relationships established between the operational variables and the kinetic parameters (Leyva-Díaz and Poyatos, 2017).

The following models, Eqs. (1)-(4), can be formulated to relate the dependent variables

$\mathrm{Y}=\lambda_{1, \mathrm{H} / \mathrm{A}} \cdot \mathrm{HRT}+\lambda_{2, \mathrm{H} / \mathrm{A}} \cdot \mathrm{X}_{\mathrm{VSS}}+\lambda_{3, \mathrm{H} / \mathrm{A}} \cdot \mathrm{e}^{-\frac{\lambda_{4, \mathrm{H} / \mathrm{A}}}{\mathrm{T}}}+\lambda_{5, \mathrm{H} / \mathrm{A}} \cdot \mathrm{SRT}$

$\mu_{\mathrm{m}}=\frac{\gamma_{1, \mathrm{H} / \mathrm{A}}}{\mathrm{HRT}}+\frac{\gamma_{2, \mathrm{H} / \mathrm{A}}}{\mathrm{X}_{\mathrm{VSS}}}+\gamma_{3, \mathrm{H} / \mathrm{A}} \cdot \mathrm{e}^{-\frac{\gamma_{4, \mathrm{H} / \mathrm{A}}}{\mathrm{T}}}+\frac{\gamma_{5, \mathrm{H} / \mathrm{A}}}{\mathrm{SRT}}$

213

$\mathrm{K}_{\mathrm{S}}=\varphi_{1, \mathrm{H} / \mathrm{A}} \cdot \mathrm{HRT}+\varphi_{2, \mathrm{H} / \mathrm{A}} \cdot \mathrm{X}_{\mathrm{VSS}}+\varphi_{3, \mathrm{H} / \mathrm{A}} \cdot \mathrm{e}^{-\frac{\varphi_{4, \mathrm{H} / \mathrm{A}}}{\mathrm{T}}}+\varphi_{5, \mathrm{H} / \mathrm{A}} \cdot \mathrm{SRT}$

214 Each of the coefficients $\lambda_{\mathrm{i}, \mathrm{H} / \mathrm{A}}, \gamma_{\mathrm{i}, \mathrm{H} / \mathrm{A},}, \varphi_{\mathrm{i}, \mathrm{H} / \mathrm{A}}$ and $\alpha_{\mathrm{i}, \mathrm{H} / \mathrm{A}}$ represents the effect of the independent variable on the dependent one. The empirical values of $\mathrm{Y}, \mu_{\mathrm{m}}, \mathrm{K}_{\mathrm{S}}$ and $\mathrm{b}$ for

216 heterotrophic and autotrophic biomass in absence and presence of NAL are shown in

217 Table 1. The theoretical values of these parameters were assessed by considering Eqs. 
218 (1)-(4) and the best-fit parameter values $\left(\lambda_{\mathrm{i}, \mathrm{H} / \mathrm{A}}, \gamma_{\mathrm{i}, \mathrm{H} / \mathrm{A}}, \varphi_{\mathrm{i}, \mathrm{H} / \mathrm{A}}\right.$ and $\left.\alpha_{\mathrm{i}, \mathrm{H} / \mathrm{A}}\right)$ were determined 219 by using the Solver Add-in function of Microsoft Excel. An objective function was defined as the weighted sum of squares of differences between the empirical and

221 theoretical values; this function was minimized to yield the most appropriate parameters 222 for the models formulated (Vining, 2003). The coefficient of determination $\left(\mathrm{R}^{2}\right)$ was 223 calculated to verify the goodness of fit, according to Eq. (5):

$224 \quad \mathrm{R}^{2}=\frac{\sum_{\mathrm{i}=1}^{\mathrm{n}}\left(\mathrm{k}_{\mathrm{i}}-\hat{\mathrm{k}}_{\mathrm{i}}\right)^{2}}{\sum_{\mathrm{i}=1}^{\mathrm{n}}\left(\mathrm{k}_{\mathrm{i}}-\overline{\mathrm{k}}\right)^{2}}$

225 where $\mathrm{k}_{\mathrm{i}}$ indicates the empirical values of the kinetic parameters, $\hat{\mathrm{k}}_{\mathrm{i}}$ represents the theoretical values of the kinetic parameters and $\overline{\mathrm{k}}$ represent the average values of the empirical kinetic parameters.

The models were optimized by considering the operation ranges of HRT (2.8-3.8 h), $\mathrm{X}_{\text {VSS }}\left(1,400-1,700 \mathrm{mgVSS} \mathrm{L}^{-1}\right), \mathrm{T}\left(12.6-14.8^{\circ} \mathrm{C}\right)$ and SRT (11.0-12.6 day) for NIPHO activated sludge reactor. The optimization was performed by the Solver Add-in function of Microsoft Excel. This provided the values of HRT, XVSS, T and SRT that maximized the $\mathrm{r}^{\prime} \mathrm{x}$ for the heterotrophic and autotrophic biomass in absence and presence of NAL. In addition, the optimum values of $\mathrm{Y}, \mu_{\mathrm{m}}, \mathrm{K}_{\mathrm{S}}, \mathrm{b}$ and $\mathrm{r}_{\mathrm{su}}$ were evaluated by considering the optimum operational conditions of HRT, Xvss, T and SRT for the NIPHO activated sludge reactor.

\subsection{Statistical analysis}

Canoco for Windows v. 4.5 (ScientiaPro, Budapest, Hungary) was applied to carry out a multivariable statistical analysis, which is described in Text S3 in the Supplementary Material. 


\section{RESULTS AND DISCUSSION}

242

243

244

245

246

247

\subsection{Dynamic and static oxygen uptake rates}

\subsubsection{Dynamic oxygen uptake rate for heterotrophic biomass ( $\left.\mathrm{R}_{\mathrm{S}, \mathrm{H}}\right)$}

Fig. S2 shows the results obtained in the exogenous respirometric tests for heterotrophic biomass of the three operation periods of NIPHO activated sludge reactor. The presence of NAL reduced the duration of the respirometric assays for the three operation periods (Fig. S2a-f). Particularly, the respirometric experiments lasted for $82.7 \mathrm{~min}, 133.4 \mathrm{~min}$ and 83.8 min in presence of NAL, and this time was increased in absence of NAL until $125.0 \mathrm{~min}, 159.3 \mathrm{~min}$ and $105.7 \mathrm{~min}$, respectively, for periods 1,2 and 3 . Thus, the presence of NAL reduced the time required by heterotrophic biomass to degrade the carbon sources. This was in accordance with the research carried out by Leyva-Díaz et al. (2017a) with other emerging pollutant as these authors obtained that the duration of heterotrophic experiments was diminished in presence of bisphenol A at similar temperature $\left(12.1^{\circ} \mathrm{C}\right)$ in an MBR system. As a whole, the maximum values for $\mathrm{RS}_{\mathrm{S}}$ increased with the addition of NAL in periods 1 and 2, and these values were similar in the third period (Fig. S2). This could be due to the fact that periods 1 and 2 worked at the most favorable operation conditions of $\mathrm{X}_{\mathrm{VSS}}\left(1,600\right.$ and $\left.1,700 \mathrm{mgVSS} \mathrm{L}^{-1}\right)$ and $\mathrm{T}$ $\left(13.7\right.$ and $\left.14.8^{\circ} \mathrm{C}\right)$ compared with the third period, which compensated the effect of NAL.

In spite of its most advantageous working conditions $\left(\mathrm{X}_{\mathrm{VSS}}=1,700 \mathrm{mgVSS} \mathrm{L}^{-1}\right.$ and $\mathrm{T}=14.8^{\circ} \mathrm{C}$ ), the experiments corresponding to the second period had the highest duration in absence and presence of NAL (159.3 min and $133.4 \mathrm{~min}$, respectively). This was probably due to the lowest value of SRT (11.0 day), which minimised the effect of $\mathrm{X}_{\mathrm{VSS}}$ and T. Nevertheless, the duration of the respirometric assay was the lowest in the third 
period in absence of NAL (105.7 min) even though the operation conditions regarding

$266 \mathrm{X}_{\mathrm{VSS}}$ and $\mathrm{T}$ were the most unfavorable $\left(\mathrm{X}_{\mathrm{VSS}}=1,400 \mathrm{mg} \mathrm{L}^{-1}\right.$ and $\left.\mathrm{T}=12.6^{\circ} \mathrm{C}\right)$, which stated

267 the highest effect of HRT in this period (HRT=3.8 h). Under the presence of NAL, the lowest duration of the respirometric tests corresponded to the first and third periods with values of $82.7 \mathrm{~min}$ and $83.8 \mathrm{~min}$, respectively. The effect of HRT prevailed over the other operation conditions in the third period, as occurred in absence of NAL. In the case of the first period, the value of SRT (12.6 day) was the most favorable and exerted a higher effect than the rest of variables.

The exogenous respiration experiments for autotrophic biomass within the NIPHO activated sludge reactor are depicted in Fig. S3 for each of the operation periods. In this case, the presence of NAL increased the duration of the experiments in periods 1 and 2 (Fig. S3a-d), which implied a higher time required by autotrophic biomass to degrade the ammonium source. Specifically, the respirometric tests lasted for $90.0 \mathrm{~min}$ and 111.5 $\mathrm{min}$ in absence of NAL, and $112.8 \mathrm{~min}$ and $186.7 \mathrm{~min}$ in presence of NAL for periods 1 and 2, respectively. However, a reverse trend was recorded in period 3, i.e. the experiment extended for $94.7 \mathrm{~min}$ in absence of NAL and $82.1 \mathrm{~min}$ in presence of NAL. This could be due to the effect of HRT, which was the highest in the third period (3.8 h). In general, the maximum values for $\mathrm{R}_{\mathrm{S}}$ decreased with the addition of NAL in all operation periods. This was probably due to the higher influence of NAL on the autotrophic biomass than the effect caused by the most favorable operation variables in the first and second periods ( $\mathrm{X}_{\mathrm{VSS}}$ and T), and in the third period (HRT).

The duration of autotrophic experiments was also the highest in the second period in absence and presence of NAL, as occurred in heterotrophic experiments. This corroborated the fact that the influence of SRT (11.0 day) compensated the most 
favorable operation conditions of $\mathrm{X}_{\mathrm{VSS}}$ and $\mathrm{T}$. However, in this case, the duration of the respirometric test was the lowest in the first period in absence of NAL (90.0 min), in which the value of SRT was the most advantageous (12.6 day). In presence of NAL, the effect of HRT $(3.8 \mathrm{~h})$ prevailed over $\mathrm{X}_{\mathrm{VSS}}$ and $\mathrm{T}$ in the third period, which had the shortest duration $(82.1 \mathrm{~min})$. Thus, for autotrophic experiments, SRT exerted a higher influence on autotrophic bacteria in period 1 in absence of NAL, and HRT had a higher effect on this kind of biomass in period 3 in presence of NAL.

\subsubsection{Static oxygen uptake rate (OUR)}

298

299

Fig. S4 depicts the endogenous respirometric assays for the three operation periods of the NIPHO activated sludge reactor. It should be highlighted that the presence of NAL lessened the maximum value of OUR, which corresponded to OUR $\mathrm{end}_{\text {, }}$ in the three operation periods. In particular, OUR end was diminished from 8.220 to $6.230 \mathrm{mgO}_{2} \mathrm{~L}^{-1}$ $\mathrm{h}^{-1}$ in the first period, from 7.321 to $5.942 \mathrm{mgO}_{2} \mathrm{~L}^{-1} \mathrm{~h}^{-1}$ in the second period, and from 4.892 to $3.934 \mathrm{mgO}_{2} \mathrm{~L}^{-1} \mathrm{~h}^{-1}$ in the third period. This trend was also observed in the research carried out by Leyva-Díaz et al. (2017a) with bisphenol A as emerging pollutant.

\subsection{Modeling and optimization of heterotrophic kinetics}

\subsubsection{Kinetic parameters}

Table 1 shows the kinetic parameters for heterotrophic and autotrophic biomass in absence and presence of NAL for the three operation stages.

The values of $\mathrm{Y}_{\mathrm{H}}$ were lower in presence of NAL ( $\left.\mathrm{Y}_{\mathrm{H}, \mathrm{NAL}}\right)$ than in absence of NAL $\left(\mathrm{Y}_{\mathrm{H}, \mathrm{n} / \mathrm{NAL}}\right)$, with reductions of $33.49 \%, 12.29 \%$ and $9.46 \%$ for periods 1,2 and 3, respectively. This resulted in a lower amount of heterotrophic biomass produced per carbonaceous substrate oxidized in presence of NAL. 
314 On the contrary, the values of $\mu_{\mathrm{m}, \mathrm{H}}$ increased in presence of NAL ( $\left.\mu_{\mathrm{m}, \mathrm{H}, \mathrm{NAL}}\right)$ if compared

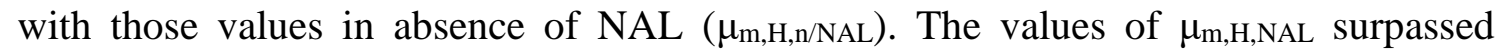
$\mu_{\mathrm{m}, \mathrm{H}, \mathrm{n} / \mathrm{NAL}}$ in $43.33 \%, 52.46 \%$ and $17.65 \%$ for periods 1,2 and 3 , respectively, implying less time to oxidize carbon source by heterotrophic bacteria in presence of NAL. The same trend could be observed for $\mathrm{K}_{\mathrm{M}}$, with higher values in presence of NAL (Table 1).

Similar results were obtained by Calero-Díaz et al. (2017), who evaluated the effect of a combination of pharmaceuticals on the heterotrophic kinetics of an MBR system. Among the three pharmaceuticals analyzed, they worked with other antibiotic (ciprofloxacin) and obtained that $\mathrm{Y}_{\mathrm{H}}$ was reduced, and $\mu_{\mathrm{m}, \mathrm{H}}$ and $\mathrm{K}_{\mathrm{M}}$ were increased in presence of these emerging pollutants.

Regarding the values of $\mathrm{b}_{\mathrm{H}}$, they were higher in absence of NAL $\left(\mathrm{b}_{\mathrm{H}, \mathrm{n} / \mathrm{NAL}}\right)$ than in presence of NAL $\left(\mathrm{b}_{\mathrm{H}, \mathrm{NAL}}\right)$, with reduction rates of $36.36 \%, 30.29 \%$ and $23.77 \%$ for periods 1,2 and 3, respectively, in presence of NAL. Thus, the presence of NAL diminished the heterotrophic decay rate, that is, the quantity of heterotrophic biomass oxidized per day. The values of OUR end (Fig. S4) supported these results as they also decreased in presence of NAL. This result was also obtained by Leyva-Díaz et al. (2017a) studying the effect of bisphenol A within an MBR system, although the reduction percentages were lower (3.91-9.17\%).

3.2.2. Degradation rate for carbon source $\left(\mathrm{r}_{\mathrm{su}, \mathrm{H}}\right)$ and net biomass growth rate $\left(\mathrm{r}^{\prime}{ }_{\mathrm{x}, \mathrm{H}}\right)$

Fig. 2a shows the values of $r_{\mathrm{su}, \mathrm{H}}$ in absence and presence of NAL for the three operation stages. It must be pointed out that the $\mathrm{r}_{\mathrm{su}, \mathrm{H}}$ increased in presence of NAL in percentages of $88.33 \%$ for period $1,62.74 \%$ for period 2 , and $23.21 \%$ for period 3 . The reason could be that the presence of NAL imposed a physiological stress on heterotrophic bacteria and heterotrophs possibly counteracted the situation by increasing the $\mathrm{r}_{\mathrm{su}, \mathrm{H}}$ in order to 
facilitate their acclimatization. Moreover, according to Bouki et al. (2013), this could be explained by the fact that environmental conditions in WWTPs are suitable for the acquisition and spread of antibiotic resistant bacteria, which may transfer resistance genes to resident bacteria. In light of this, Zhang et al. (2015) first time identified and characterized antibiotic-resistant heterotrophic bacteria from different WWTPs. Vasiliadou et al. (2018) also studied the effect of pharmaceutical compounds on mixed culture from activated sludge using respirometric method and obtained an adaptation of microorganisms that was based on modifications of microbial community, increasing its resistance to pharmaceuticals. In this way, the degradation of carbon source occurred faster in presence of NAL than in absence of this antibiotic at a biodegradation rate of NAL of $1.73 \pm 0.14 \%$ during heterotrophic test. The highest values of $r_{\mathrm{su}, \mathrm{H}}$ corresponded to heterotrophic biomass from the second period in absence and presence of NAL (25.88 and $42.12 \mathrm{mgO}_{2} \mathrm{~L}^{-1} \mathrm{~h}^{-1}$, respectively), which could be due to the operation at the highest values of $\mathrm{X}_{\mathrm{VSS}}\left(1,700 \mathrm{mgVSS} \mathrm{L}^{-1}\right)$ and $\mathrm{T}\left(14.8^{\circ} \mathrm{C}\right)$ (Table $\left.\mathrm{S} 1\right)$. Fig. 2b represents the values of $r^{\prime}{ }_{x, H}$ in absence and presence of NAL. The trend was similar to that obtained for $r_{s u, H}$, with an increase of $r^{\prime}{ }_{x, H}$ in presence of NAL. Heterotrophic biomass subjected to the operation conditions of period 2 had the highest $r^{\prime}{ }_{x, H}$ in presence of NAL (6.73 $\left.\mathrm{mgVSS} \mathrm{L}^{-1} \mathrm{~h}^{-1}\right)$, which was probably caused by the most favorable operation conditions of this period regarding $\mathrm{X}_{\mathrm{VSS}}$ and $\mathrm{T}$, as happened previously for $\mathrm{r}_{\mathrm{su}, \mathrm{H}}$. In relation to the operation in absence of NAL, heterotrophic biomass corresponding to period 3 showed the highest $\mathrm{r}_{\mathrm{x}, \mathrm{H}}^{\prime}\left(2.91 \mathrm{mgVSS} \mathrm{L}^{-1} \mathrm{~h}^{-1}\right)$, which could be explained by the highest effect of HRT (3.8 h).

\subsubsection{Modeling and optimization}

Regarding the mathematical models to fit the heterotrophic kinetics depending on HRT, 

had a high goodness of fit for the kinetic parameters characterizing the heterotrophic bacteria within the NIPHO activated sludge reactor. Moreover, Fig. 3a-b shows the results of the multivariable statistical analysis for heterotrophic kinetic modeling in absence and presence of NAL.

In light of this, in absence of NAL (Fig. 3a), $\mathrm{Y}_{\mathrm{H}, \mathrm{n} / \mathrm{NAL}}$ showed a positive correlation with SRT and a strongly negative correlation with HRT, which was supported by the fitting parameters $\lambda_{5, \mathrm{H}}(0.02416)$ and $\lambda_{1, \mathrm{H}}(-0.00377)$, respectively. A similar trend was observed for $\mu_{\mathrm{m}, \mathrm{H}, \mathrm{n} / \mathrm{NAL}}$ and $\mathrm{b}_{\mathrm{H}, \mathrm{n} / \mathrm{NAL}}$, although the effect of SRT on these parameters was slightly lower and the influence of $\mathrm{X}_{\mathrm{VSS}}$ and $\mathrm{T}$ was slightly higher than for $\mathrm{Y}_{\mathrm{H}, \mathrm{n} / \mathrm{NAL}}$. This was corroborated by the coefficients $\gamma_{\mathrm{i}, \mathrm{H}}$ and $\alpha_{\mathrm{i}, \mathrm{H}}$ in absence of NAL. In relation to

$374 \mathrm{~K}_{\mathrm{M}, \mathrm{n} / \mathrm{NAL}}$, it was directly proportional to $\mathrm{X}_{\mathrm{VSS}}$ and $\mathrm{T}$, as indicated by the triplot diagram and the fitting parameters $\varphi_{2, \mathrm{H}}(0.00208), \varphi_{3, \mathrm{H}}(0.01107)$ and $\varphi_{4, \mathrm{H}}(0.00002)$. However, it was negatively correlated with SRT $\left(\varphi_{5, \mathrm{H}}=-0.31326\right)$ and HRT had almost no influence on it as the angles between these vectors are approximately $90^{\circ}$. Furthermore, $\mathrm{r}_{\mathrm{su}, \mathrm{H}, \mathrm{n} / \mathrm{NAL}}$ had a strongly positive correlation with $\mathrm{X}_{\mathrm{VSS}}$ and $\mathrm{T}$, and $\mathrm{r}_{\mathrm{x}, \mathrm{H}, \mathrm{n} / \mathrm{NAL}}$ was positively correlated with HRT (Fig. 3a). This confirmed the previous results in which heterotrophic biomass from period 2 worked at the most favorable operation conditions of $\mathrm{X}_{\mathrm{VSS}}$ and $\mathrm{T}$ and showed the highest values for $\mathrm{r}_{\mathrm{su}, \mathrm{H}, \mathrm{n} / \mathrm{NAL}}$, and heterotrophic biomass from period 3 operated at the greatest HRT and presented the highest value of $\mathrm{r}^{\prime}{ }_{\mathrm{X}, \mathrm{H}, \mathrm{n} / \mathrm{NAL}}$. The optimum operational conditions in terms of HRT, Xvss, T and SRT were $3.8 \mathrm{~h}$, 1,566 $\mathrm{mgVSS} \mathrm{L}^{-1}, 12.6^{\circ} \mathrm{C}$ and 12.6 day, respectively (Table 2), which allowed to obtain the optimum values of $23.96 \mathrm{mgO}_{2} \mathrm{~L}^{-1} \mathrm{~h}^{-1}$ and $3.93 \mathrm{mgVSS} \mathrm{L}^{-1} \mathrm{~h}^{-1}$ for $\mathrm{r}_{\mathrm{su}, \mathrm{H}, \mathrm{n} / \mathrm{NAL}}$ and

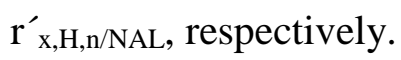


387

The presence of NAL modified the results obtained in absence of NAL, as shown in Fig. 3b. In this way, $\mathrm{Y}_{\mathrm{H}, \mathrm{NAL}}$ had a slightly positive correlation with HRT and SRT. Its correlation with $\mathrm{X}_{\mathrm{VSS}}$ and $\mathrm{T}$ was strongly negative, according to the values $\lambda_{\mathrm{i}, \mathrm{H}}$ from Table 2. A similar trend was observed for $\mu_{\mathrm{m}, \mathrm{H}, \mathrm{NAL}}$ and $\mathrm{b}_{\mathrm{H}, \mathrm{NAL}}$, although the effect of SRT on these parameters was slightly higher and the influence of HRT was slightly lower than for $\mathrm{Y}_{\mathrm{H}, \mathrm{NAL}}$. This was confirmed by the coefficients $\gamma_{\mathrm{i}, \mathrm{H}}$ and $\alpha_{\mathrm{i}, \mathrm{H}}$ in presence of NAL. Regarding the $\mathrm{K}_{\mathrm{M}, \mathrm{NAL}}$, it had a direct proportionality with $\mathrm{X}_{\mathrm{VSS}}$ and $\mathrm{T}$, as demonstrated by the fitting parameters $\varphi_{2, \mathrm{H}}(0.00900), \varphi_{3, \mathrm{H}}(-0.14500)$ and $\varphi_{4, \mathrm{H}}(-$

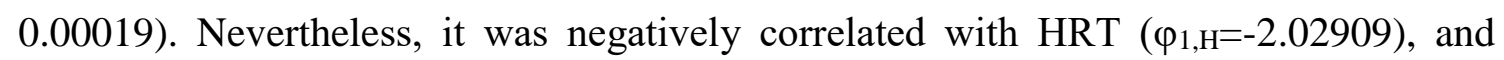
SRT did not practically affect it. In presence of NAL, SRT replaced XVSS and T, and was the operation variable with the highest influence on $\mathrm{r}_{\mathrm{su}, \mathrm{H}, \mathrm{NAL}}$, and HRT continued to have the greatest effect on $r^{\prime}{ }_{x, H, N A L}$ in presence of NAL (Fig. 3b). The optimum values corresponding to the operational variables were $2.8 \mathrm{~h}$ for $\mathrm{HRT}, 1,566 \mathrm{mgVSS} \mathrm{L}^{-1}$ for $\mathrm{X}_{\mathrm{VSS}}, 14.8^{\circ} \mathrm{C}$ for $\mathrm{T}$ and 11.0 day for SRT, which implied optimum values for $\mathrm{r}_{\mathrm{su}, \mathrm{H}, \mathrm{NAL}}$ and $\mathrm{r}_{\mathrm{x}, \mathrm{H}, \mathrm{NAL}}^{\prime}$ that practically doubled those obtained in absence of NAL $\left(54.52 \mathrm{mgO}_{2} \mathrm{~L}^{-1}\right.$ $\mathrm{h}^{-1}$ and $6.68 \mathrm{mgVSS} \mathrm{L}^{-1} \mathrm{~h}^{-1}$, respectively).

\subsection{Modeling and optimization of autotrophic kinetics}

\subsubsection{Kinetic parameters}

The autotrophic kinetic parameters in absence and presence of NAL are shown in Table 1 for the different operation periods.

The values of $\mathrm{Y}_{\mathrm{A}}$ were higher in presence of NAL $\left(\mathrm{Y}_{\mathrm{A}, \mathrm{NAL}}\right)$ than in absence of NAL $\left(\mathrm{Y}_{\mathrm{A}, \mathrm{n} / \mathrm{NAL}}\right)$, with increases of $1.20 \%, 18.17 \%$ and $26.67 \%$ for periods 1,2 and 3 , respectively. This implied a higher amount of autotrophic biomass produced per nitrogenous substrate oxidized in presence of NAL. 
411 However, the values of $\mu_{\mathrm{m}, \mathrm{A}}$ decreased in presence of NAL $\left(\mu_{\mathrm{m}, \mathrm{A}, \mathrm{NAL}}\right)$ in relation to 412 those values in absence of NAL $\left(\mu_{\mathrm{m}, \mathrm{A}, \mathrm{n} / \mathrm{NAL}}\right)$, with reduction percentages of $63.26 \%$, $41359.27 \%$ and $64.71 \%$ for periods 1,2 and 3, respectively. Thus, the time required to 414 oxidize ammonium source by autotrophic bacteria was higher in presence of NAL than 415 in absence of this antibiotic. The same trend was obtained for $\mathrm{K}_{\mathrm{NH}}$, with lower values in 416 presence of NAL.

417 In relation to the values of $b_{A}$, they were higher in absence of NAL $\left(b_{A, n / N A L}\right)$ than in 418 presence of NAL $\left(b_{A, N A L}\right)$, as occurred for $b_{H}$. In this case, the presence of NAL also 419 lessened the autotrophic decay rate, that is, the quantity of autotrophic biomass oxidized 420 per day. In particular, the reduction percentages were $38.67 \%, 30.27 \%$ and $20.74 \%$ for 421 periods 1, 2 and 3, respectively. This was confirmed by the decrease of OUR end in 422 presence of NAL, as shown in Fig. S4. It should be highlighted that the autotrophic 423 decay rate was lower in period 1 in relation to periods 2 and 3, which could be due to its higher SRT (12.6 day).

Fig. 2c depicts the values of $r_{\mathrm{su}, \mathrm{A}}$ in absence and presence of NAL for the different operation periods. The presence of NAL reduced the $\mathrm{r}_{\mathrm{su}, \mathrm{A}}$ in $61.99 \%$ for the first period, $64.29 \%$ for the second period and $67.70 \%$ for the third period, which implied that the degradation of ammonium source occurred slower in presence of NAL at a biodegradation rate of NAL of $1.45 \pm 0.12 \%$ during autotrophic test. This trend was opposed to that observed for heterotrophic biomass. The highest values of $r_{\mathrm{su}, \mathrm{A}}$ were registered for autotrophic biomass from period 2 in absence and presence of NAL (36.78 $\mathrm{mgN} \mathrm{L}^{-1} \mathrm{~h}^{-1}$ and $13.14 \mathrm{mgN} \mathrm{L}^{-1} \mathrm{~h}^{-1}$, respectively), which could be caused by the working at the most favorable operation conditions of $\mathrm{X}_{\mathrm{VSS}}$ and $\mathrm{T}\left(1,700 \mathrm{mgVSS} \mathrm{L}^{-1}\right.$ and $14.8^{\circ} \mathrm{C}$, respectively). Fig. $2 \mathrm{~d}$ shows the values of $\mathrm{r}_{\mathrm{x}, \mathrm{A}}$ in absence and presence of 
436 NAL. For $\mathrm{r}_{\mathrm{x}, \mathrm{A}}$, the presence of NAL also reduced its value for periods 1,2 and 3, as

437 occurred for $\mathrm{r}_{\mathrm{su}, \mathrm{A}}$. Autotrophic biomass from the third period showed values of $\mathrm{r}_{\mathrm{x}, \mathrm{A}}^{\prime}$

438 slightly higher than those obtained from the first and second periods both in absence of

439 NAL and in presence of this antibiotic (25.37 $\mathrm{mgVSS} \mathrm{L}^{-1} \mathrm{~h}^{-1}$ and $10.29 \mathrm{mgVSS} \mathrm{L}^{-1} \mathrm{~h}^{-1}$,

440 respectively). This could be explained by the highest value of HRT $(3.8 \mathrm{~h})$

441 characterizing this operation period.

442 If the values of $r_{s u, A}$ and $r^{\prime}{ }_{x, A}$ are compared with the corresponding values of $r_{s u, H}$ and $443 \mathrm{r}_{\mathrm{x}, \mathrm{H}}^{\prime}$, it is necessary to indicate that NAL exerted a negative effect on autotrophic 444 biomass in relation to the influence observed on heterotrophic biomass within the 445 NIPHO activated sludge reactor.

446 In light of this, Kraigher et al. (2008) studied the influence of pharmaceuticals 447 (ibuprofen, naproxen, ketoprofen, diclofenac and clofibric acid) on the structure of activated sludge bacterial communities from a bioreactor that worked at a HRT of $48 \mathrm{~h}$ and at a SRT of over 100 days. They obtained that the genus Nitrospira, which represented $8 \%$ of the total community, was only found in the bioreactor without

451 pharmaceuticals. This indicated that nitrite-oxidizing bacteria, which play a key role for 452 the second stage of nitrification in WWTPs, were affected in presence of 453 pharmaceuticals. Dokianakis et al. (2004) obtained similar results to those shown by 454 Kraigher et al. (2008). This was in accordance with the partial inhibitory effect of NAL on autotrophic bacteria in the current research.

\subsubsection{Modeling and optimization}

457 Mathematical modeling fitting the autotrophic kinetics depending on HRT, $\mathrm{X}_{\mathrm{VSS}}$, T and 458 SRT in absence and presence of NAL had a higher goodness of fit than that for heterotrophic kinetics, with values for $\mathrm{R}^{2}$ varying between 0.99913 and 0.99997 (Table 
autotrophic kinetic modeling in absence and presence of NAL. In absence of NAL (Fig. correlation with HRT. The influence of SRT was slightly low, as the angle between the vectors was almost of $90^{\circ}$. In the case of $\mu_{\mathrm{m}, \mathrm{A}, \mathrm{n} / \mathrm{NAL}}$, it was positively correlated with HRT, $X_{V s s}$ and T, as indicated by the values $\gamma_{1, A}, \gamma_{2, A}, \gamma_{3, A}$ and $\gamma_{4, A}$, while it was strongly negative correlated with $\operatorname{SRT}\left(\gamma_{5, \mathrm{~A}}\right)$. Regarding $\mathrm{K}_{\mathrm{NH}, \mathrm{n} / \mathrm{NAL}}$, it had a positive correlation with HRT, which was supported by the fitting parameter $\varphi_{1, \mathrm{~A}}(0.11956)$. The influence of $\mathrm{X}_{\mathrm{VSS}}$ and $\mathrm{T}$ on this kinetic parameter was negligible, as shown the angles between the vectors (close to $90^{\circ}$ ) and the low values of $\varphi_{2, \mathrm{~A}}, \varphi_{3, \mathrm{~A}}$ and $\varphi_{4, \mathrm{~A}}$. In relation to the influence of SRT, the trend was similar to that observed for $\mu_{\mathrm{m}, \mathrm{A}, \mathrm{n} / \mathrm{NAL}}$. The correlation between $\mathrm{b}_{\mathrm{A}, \mathrm{n} / \mathrm{NAL}}$ and the operational conditions $\mathrm{X}_{\mathrm{VSS}}$ and $\mathrm{T}$ was strongly positive. This was corroborated by the coefficients $\alpha_{2, \mathrm{~A}}(0.56121), \alpha_{3, \mathrm{~A}}(0.23255)$ and $\alpha_{4, \mathrm{~A}}(-0.14763)$. However, $\mathrm{b}_{\mathrm{A}, \mathrm{n} / \mathrm{NAL}}$ had a negative correlation with SRT $\left(\alpha_{5, \mathrm{~A}}=-0.64990\right)$. The angle formed between the vectors corresponding to $\mathrm{b}_{\mathrm{A}, \mathrm{n} / \mathrm{NAL}}$ and HRT was $90^{\circ}$, which meant that this variable did not practically influence on this kinetic parameter. Moreover, $\mathrm{r}_{\mathrm{su}, \mathrm{A}, \mathrm{n} / \mathrm{NAL}}$ had a positive correlation with $\mathrm{XVSS}_{\mathrm{VSS}}$ and $\mathrm{T}$, and $\mathrm{r}_{\mathrm{x}, \mathrm{A}, \mathrm{n} / \mathrm{NAL}}$ showed a 477 positive correlation with SRT (Fig. 3c). This corroborated the previous results in which autotrophic biomass from period 2 had the highest values for $\mathrm{r}_{\mathrm{su}, \mathrm{A}, \mathrm{n} / \mathrm{NAL}}$ at the most favorable operation conditions of $\mathrm{X}_{\mathrm{VSS}}$ and $\mathrm{T}$. The optimum values for $\mathrm{r}_{\mathrm{Su}, \mathrm{A}, \mathrm{n} / \mathrm{NAL}}$ and $\mathrm{r}^{\prime}{ }_{\mathrm{X}, \mathrm{A}, \mathrm{n} / \mathrm{NAL}}$ were $69.21 \mathrm{mgN} \mathrm{L}^{-1} \mathrm{~h}^{-1}$ and $55.02 \mathrm{mgVSS} \mathrm{L}^{-1} \mathrm{~h}^{-1}$, respectively, at HRT of 3.8 $\mathrm{h}, \mathrm{XVSS}_{\mathrm{VS}}$ of $125 \mathrm{mgVSS} \mathrm{L}^{-1}$, T of $12.6^{\circ} \mathrm{C}$ and SRT of 12.6 day (Table 2). Fig. $3 \mathrm{~d}$ shows the differences generated as a consequence of the effect of NAL on autotrophic biomass in relation to the absence of NAL. In this regard, $\mathrm{Y}_{\mathrm{A}, \mathrm{NAL}}$ showed a slightly positive correlation with HRT and SRT, and it was inversely proportional to $\mathrm{X}_{\mathrm{VSS}}$ and $\mathrm{T}$, as supported by the fitting parameters $\lambda_{\mathrm{i}, \mathrm{A}}$. In general, a similar trend was 
observed for $\mu_{\mathrm{m}, \mathrm{A}, \mathrm{NAL}}, \mathrm{K}_{\mathrm{NH}, \mathrm{NAL}}$ and $\mathrm{b}_{\mathrm{A}, \mathrm{NAL}}$, with a positive correlation regarding $\mathrm{X}_{\mathrm{VSS}}$ and T, a slightly positive correlation with HRT, and a strongly negative correlation with SRT, as indicated by the fitting parameters $\gamma_{\mathrm{i}, \mathrm{A}}, \varphi_{\mathrm{i}, \mathrm{A}}$ and $\alpha_{\mathrm{i}, \mathrm{A}}$, respectively. In presence of NAL, Xvss and $T$ continued to have influence on $r_{\mathrm{su}, \mathrm{A}, \mathrm{NAL}}$ and their effect was higher than in absence of NAL due to the lower angles between the vectors corresponding to $\mathrm{X}_{\mathrm{VSS}}, \mathrm{T}$ and $\mathrm{r}_{\mathrm{Su}, \mathrm{A}, \mathrm{NAL}}$. Regarding $\mathrm{r}_{\mathrm{X}, \mathrm{A}, \mathrm{NAL}}$, it was directly proportional to SRT, as occurred in absence of NAL, and had also a slightly direct proportionality with HRT (Fig. 3d). This confirmed the previous results in which autotrophic biomass from the third period had a slightly higher value for $\mathrm{r}^{\prime}{ }_{\mathrm{x}, \mathrm{A}, \mathrm{NAL}}$ than in the rest of operation periods due to its operation at the highest HRT (3.8 h). In this case, the optimum values for the operational conditions were identical to those obtained in absence of NAL (HRT $=3.8 \mathrm{~h}$, $\mathrm{X}_{\mathrm{vSS}}=125 \mathrm{mgVSS} \mathrm{L}^{-1}, \mathrm{~T}=12.6^{\circ} \mathrm{C}$ and $\mathrm{SRT}=12.6$ day). This implied optimum values for $\mathrm{r}_{\mathrm{Su}, \mathrm{A}, \mathrm{NAL}}$ and $\mathrm{r}_{\mathrm{X}, \mathrm{A}, \mathrm{NAL}}^{\prime}$ of $22.02 \mathrm{mgN} \mathrm{L}^{-1} \mathrm{~h}^{-1}$ and $20.23 \mathrm{mgVSS} \mathrm{L}^{-1} \mathrm{~h}^{-1}$, respectively (Table

2).

It should be highlighted that the different models were optimized for the operation ranges of HRT $(2.8-3.8 \mathrm{~h}), \mathrm{XVSS}_{\mathrm{VS}}\left(1,400-1,700 \mathrm{mgVSS} \mathrm{L}^{-1}\right), \mathrm{T}\left(12.6-14.8^{\circ} \mathrm{C}\right)$ and SRT (11.0-12.6 day) in the NIPHO activated sludge reactor. Thus, this methodology provides a preview to achieve the optimum operation conditions for desirable responses in relation to the biological processes of organic matter and nitrogen removal in absence and presence of NAL, and to carry out a more precise control of these processes. To the best of our knowledge, obtaining mixed liquor samples from a real WWTP at three different operation conditions is novel for the kinetic modeling and optimization of biological processes. 


\section{CONCLUSIONS}

512 The following conclusions were drawn from the kinetic modeling and optimization of a

513 NIPHO activated sludge reactor treating municipal wastewater under the influence of

514 shock additions of nalidixic acid (NAL) for three operation periods, highlighting the

515 novelty of obtaining activated sludge samples from a real WWTP at three different

516 operation conditions:

517 - The degradation rate for carbon source $\left(\mathrm{r}_{\mathrm{su}, \mathrm{H}}\right)$ increased in presence of NAL, which

518 implied a faster consumption of carbon source than in absence of NAL. However,

519 degradation rate for ammonium source $\left(\mathrm{r}_{\mathrm{su}, \mathrm{A}}\right)$ diminished in presence of NAL, which

520 meant a slower degradation of nitrogen source than in absence of NAL. Similar

521 trends were observed for the net heterotrophic biomass growth rate $\left(\mathrm{r}_{\mathrm{x}, \mathrm{H}}^{\prime}\right)$ and net

522 autotrophic biomass growth rate $\left(\mathrm{r}^{\prime}{ }_{\mathrm{x}, \mathrm{A}}\right)$. Thus, the heterotrophic biomass of the

523 NIPHO activated sludge reactor was not inhibited by the presence of NAL, showing

524 an adaptive capacity to improve $\mathrm{r}_{\mathrm{su}, \mathrm{H}}$ and $\mathrm{r}_{\mathrm{x}, \mathrm{H}}^{\prime}$. However, the autotrophic biomass was

525 negatively affected by the presence of NAL, reducing the values of $\mathrm{r}_{\mathrm{su}, \mathrm{A}}$ and $\mathrm{r}_{\mathrm{x}, \mathrm{A}}$.

526 - Heterotrophic and autotrophic kinetic performance in terms of yield coefficient (Y),

527 maximum specific growth rate $\left(\mu_{\mathrm{m}}\right)$, half-saturation coefficient for substrate source

$528\left(\mathrm{~K}_{\mathrm{S}}\right)$ and decay coefficient (b) could be modeled depending on HRT, XVSS, T and

529 SRT, according to the following functions:

530

531

532

$\mathrm{Y}=\lambda_{1, \mathrm{H} / \mathrm{A}} \cdot \mathrm{HRT}+\lambda_{2, \mathrm{H} / \mathrm{A}} \cdot \mathrm{X}_{\mathrm{VSS}}+\lambda_{3, \mathrm{H} / \mathrm{A}} \cdot \mathrm{e}^{-\frac{\lambda_{4, \mathrm{H} / \mathrm{A}}}{\mathrm{T}}}+\lambda_{5, \mathrm{H} / \mathrm{A}} \cdot \mathrm{SRT}$

$\mu_{m}=\frac{\gamma_{1, H / A}}{H R T}+\frac{\gamma_{2, H / A}}{X_{V S S}}+\gamma_{3, H / A} \cdot e^{-\frac{\gamma_{4, H / A}}{T}}+\frac{\gamma_{5, H / A}}{S R T}$

$\mathrm{K}_{\mathrm{S}}=\varphi_{1, \mathrm{H} / \mathrm{A}} \cdot \mathrm{HRT}+\varphi_{2, \mathrm{H} / \mathrm{A}} \cdot \mathrm{X}_{\mathrm{VSS}}+\varphi_{3, \mathrm{H} / \mathrm{A}} \cdot \mathrm{e}^{-\frac{\varphi_{4, \mathrm{H} / \mathrm{A}}}{\mathrm{T}}}+\varphi_{5, \mathrm{H} / \mathrm{A}} \cdot \mathrm{SRT}$

533

$\mathrm{b}=\frac{\alpha_{1, \mathrm{H} / \mathrm{A}}}{\mathrm{HRT}}+\frac{\alpha_{2, \mathrm{H} / \mathrm{A}}}{\mathrm{X}_{\mathrm{VSS}}}+\alpha_{3, \mathrm{H} / \mathrm{A}} \cdot \mathrm{e}^{-\frac{\alpha_{4, \mathrm{H} / \mathrm{A}}}{\mathrm{T}}}+\frac{\alpha_{5, \mathrm{H} / \mathrm{A}}}{\mathrm{SRT}}$ 
- The variables with the highest influence on $r_{\mathrm{su}, \mathrm{H}}$ and $\mathrm{r}_{\mathrm{su}, \mathrm{A}}$ were the biomass concentration (XVss) and temperature (T), with the exception for $\mathrm{r}_{\mathrm{su}, \mathrm{H}}$ in presence of NAL that was more affected by sludge retention time (SRT). Hydraulic retention time (HRT) was the variable with the greatest effect on $\mathrm{r}_{\mathrm{x}, \mathrm{H}}$, and SRT had the highest influence on $r^{\prime}{ }_{x, A}$ in absence and presence of NAL.

\section{Acknowledgements}

Authors would like to acknowledge ACUAES (public consortium for the management of MWWTPs in Spain) and to Eva María Álvarez (EDAR-Villapérez) for providing us the required samples from the WWTP of Villapérez, Asturias (Spain).

\section{Appendix. Supplementary material}

Supplementary data associated with this article can be found, in the online version, at ...

\section{Nomenclature}

b decay coefficient

$\mathrm{b}_{\mathrm{A}, \mathrm{NAL}}$ decay coefficient for autotrophic biomass in presence of NAL

$\mathrm{b}_{\mathrm{A}, \mathrm{n} / \mathrm{NAL}}$ decay coefficient for autotrophic biomass in absence of NAL

$b_{H, N A L}$ decay coefficient for heterotrophic biomass in presence of NAL

$\mathrm{b}_{\mathrm{H}, \mathrm{n} / \mathrm{NAL}}$ decay coefficient for heterotrophic biomass in absence of NAL

BNR biological nutrient removal

COD chemical oxygen demand

DCA detrended correspondence analysis

DO dissolved oxygen

HRT hydraulic retention time

$\mathrm{K}_{\mathrm{M}, \mathrm{NAL}}$ half-saturation coefficient for carbon source in presence of NAL

$\mathrm{K}_{\mathrm{M}, \mathrm{n} / \mathrm{NAL}}$ half-saturation coefficient for carbon source in absence of NAL

$\mathrm{K}_{\mathrm{NH}, \mathrm{NAL}}$ half-saturation coefficient for ammonium source in presence of NAL

$\mathrm{K}_{\mathrm{NH}, \mathrm{n} / \mathrm{NAL}}$ half-saturation coefficient for ammonium source in absence of NAL

KS half-saturation coefficient for substrate source

MLSS mixed liquor suspended solids

NAL nalidixic acid

OUR static oxygen uptake rate 


$\begin{array}{ll}\mathrm{RDA} & \text { redundancy analysis } \\ \mathrm{r}_{\mathrm{su}} & \text { substrate degradation rate } \\ \mathrm{r}_{\mathrm{su}, \mathrm{A}, \mathrm{NAL}} & \text { degradation rate for ammonium source in presence of NAL } \\ \mathrm{r}_{\mathrm{Su}, \mathrm{A}, \mathrm{n} / \mathrm{NAL}} & \text { degradation rate for ammonium source in absence of NAL } \\ \mathrm{r}_{\mathrm{su}, \mathrm{H}, \mathrm{NAL}} & \text { degradation rate for carbon source in presence of NAL } \\ \mathrm{r}_{\mathrm{su}, \mathrm{H}, \mathrm{n} / \mathrm{NAL}} & \text { degradation rate for carbon source in absence of NAL } \\ \mathrm{r}^{\prime}{ }_{\mathrm{X}} & \text { net biomass growth rate } \\ \mathrm{r}^{\prime}{ }_{\mathrm{X}, \mathrm{A}, \mathrm{NAL}} & \text { net autotrophic biomass growth rate in presence of NAL } \\ \mathrm{r}^{\prime}{ }_{\mathrm{X}, \mathrm{A}, \mathrm{n} / \mathrm{NAL}} & \text { net autotrophic biomass growth rate in absence of NAL } \\ \mathrm{r}^{\prime}{ }_{\mathrm{X}, \mathrm{H}, \mathrm{NAL}} & \text { net heterotrophic biomass growth rate in presence of NAL } \\ \mathrm{r}^{\prime}{ }_{\mathrm{x}, \mathrm{H}, \mathrm{n} / \mathrm{NAL}} & \text { net heterotrophic biomass growth rate in absence of NAL } \\ \mathrm{R}_{\mathrm{S}} & \text { dynamic oxygen uptake rate } \\ \mathrm{R}_{\mathrm{S}, \mathrm{A}} & \text { dynamic oxygen uptake rate for autotrophic biomass } \\ \mathrm{R}_{\mathrm{S}, \mathrm{H}} & \text { dynamic oxygen uptake rate for heterotrophic biomass } \\ \mathrm{SRT} & \text { sludge retention time } \\ \mathrm{T} & \text { temperature } \\ \mathrm{WWTP} & \text { wastewater treatment plant } \\ \mathrm{X}_{\mathrm{VSS}} & \text { biomass concentration as mixed liquor volatile suspended solids } \\ \mathrm{X}_{\mathrm{A}} & \text { concentration of autotrophic biomass } \\ \mathrm{X}_{\mathrm{H}} & \text { concentration of heterotrophic biomass } \\ \mathrm{X}_{\mathrm{T}} & \text { total biomass concentration } \\ \mathrm{Y} & \text { yield coefficient } \\ \mathrm{Y}_{\mathrm{A}, \mathrm{NAL}} & \text { yield coefficient for autotrophic biomass in presence of NAL } \\ \mathrm{Y}_{\mathrm{A}, \mathrm{n} / \mathrm{NAL}} & \text { yield coefficient for autotrophic biomass in absence of NAL } \\ \mathrm{Y}_{\mathrm{H}, \mathrm{NAL}} & \text { yield coefficient for heterotrophic biomass in presence of NAL } \\ \mathrm{Y}_{\mathrm{H}, \mathrm{n} / \mathrm{NAL}} & \text { yield coefficient for heterotrophic biomass in absence of NAL } \\ & \end{array}$

Greek symbols

$\lambda \quad$ fitting parameter for yield coefficient

$\gamma \quad$ fitting parameter for maximum specific growth rate

$\varphi \quad$ fitting parameter for half-saturation coefficient for substrate source

$\alpha \quad$ fitting parameter for decay coefficient

$\mu_{\mathrm{m}} \quad$ maximum specific growth rate

$\mu_{\mathrm{m}, \mathrm{A}, \mathrm{NAL}}$ maximum specific growth rate for autotrophic biomass in presence of NAL

$\mu_{\mathrm{m}, \mathrm{A}, \mathrm{n} / \mathrm{NAL}}$ maximum specific growth rate for autotrophic biomass in absence of NAL

$\mu_{\mathrm{m}, \mathrm{H}, \mathrm{NAL}}$ maximum specific growth rate for heterotrophic biomass in presence of NAL

$\mu_{\mathrm{m}, \mathrm{H}, \mathrm{n} / \mathrm{NAL}}$ maximum specific growth rate for heterotrophic biomass in absence of NAL

\section{$548 \quad$ References}

549 Abu-Alhail, S., Lu, X.W., 2014. Experimental investigation and modeling of innovative

550 five-tank anaerobic-anoxic/oxic process. Appl. Math. Model. 38 (1), 278-290.

551 APHA, 2012. Standard Methods for the Examination of Water and Wastewater, 22nd

552 ed. American Public Health Association, Washington DC. 
553 Bouki, C., Venieri, D., Diamadopoulos, E., 2013. Detection and fate of antibiotic

554 resistant bacteria in wastewater treatment plants: a review. Ecotox. Environ. Safe. 91, $5551-9$

556 Calero-Díaz, G., Monteoliva-García, A., Leyva-Díaz, J.C., López-López, C., Martín557 Pascual, J., Torres, J.C., Poyatos, J.M., 2017. Impact of ciprofloxacin, carbamazepine 558 and ibuprofen on a membrane bioreactor system: Kinetic study and biodegradation 559 capacity. J. Chem. Technol. Biot. 92, 2944-2951.

560 Dokianakis, S.N., Kornaros, M.E., Lyberatos, G., 2004. On the effect of 561 pharmaceuticals on bacterial nitrite oxidation. Water Sci. Technol. 50 (5), 341-346.

562 Gelbrand, H., Miller-Petrie, M., Pant, S., Gandra, S., Levinson, J., Barter, D., White, A., 563 Laxminarayan, R., Ganguly, N., Kariuki, S., 2015. The State of the World's Antibiotics 564 2015. Wound Healing S. Afr. 8 (2), 30-34.

565 Huang, C.H., Renew, J.E., Smeby, K.L., Pinkerston, K., Sedlak, D.L., 2001. 566 Assessment of potential antibiotic contaminants in water and preliminary occurrence 567 analysis. Water Resour. Update 120, 30-40.

568 Ibrahim, M.S., Shehatta, I.S., Sultan, M.R., 2002. Cathodic adsorptive stripping 569 voltammetric determination of nalidixic acid in pharmaceuticals, human urine and 570 serum. Talanta 56, 471-479.

571 Kim, B.C., Kim, S., Shin, T., Kim, H., Sang, B.I., 2013. Comparison of the bacterial 572 communities in anaerobic, anoxic, and oxic chambers of a pilot $\mathrm{A}^{2} \mathrm{O}$ process using 573 pyrosequencing analysis. Curr. Microbiol. 66 (6), 555-565. 
574 Kraigher, B., Kosjek, T., Heath, E., Kompare, B., Mandic-Mulec, I., 2008. Influence of

575 pharmaceutical residues on the structure of activated sludge bacterial communities in 576 wastewater treatment bioreactors. Water Res. 42, 4578-4588.

577 Kummerer, K., 2009. Antibiotics in the aquatic environment: a review e part II.

578 Chemosphere 75, 435-441.

579 Kümmerer, K., 2013. Pharmaceuticals in the Environment: sources, fate, effects and 580 risks, Springer, Berlin.

581 Laera, G., Cassano, D., Lopez, A., Pinto, A., Pollice, A., Ricco, G., Mascolo, G., 2012.

582 Removal of Organics and Degradation Products from Industrial Wastewater by a 583 Membrane Bioreactor Integrated with Ozone or UV/H2O2 Treatment. Environ. Sci. 584 Technol. 46, 1010-1018.

585 Lai, T.M., Dang, H.V., Nguyen, D.D., Yim, S., Hur, J., 2011. Wastewater treatment 586 using a modified $\mathrm{A}^{2} \mathrm{O}$ process based on fiber polypropylene media. J. Environ. Sci. 587 Health A Tox. Hazard. Subst. Environ. Eng. 46 (10), 1068-1074.

588 Lekunberri, I., Villagrasa, M., Balcázar, J.L., Borrego, C.M., 2017. Contribution of 589 bacteriophage and plasmid DNA to the mobilization of antibiotic resistance genes in a 590 river receiving treated wastewater discharges. Sci. Total Environ. 601-602, 206-209.

591 Leyva-Díaz, J.C., Calderón, K., Rodríguez, F.A., González-López, J., Hontoria, E., 592 Poyatos, J.M., 2013. Comparative kinetic study between moving bed biofilm reactor593 membrane bioreactor and membrane bioreactor systems and their influence on organic 594 matter and nutrients removal. Biochem. Eng. J. 77, 28-40. 
595 Leyva-Díaz, J.C., Muñío, M.M., González-López, J., Poyatos, J.M., 2016.

596 Anaerobic/anoxic/oxic configuration in hybrid moving bed biofilm reactor-membrane

597 bioreactor for nutrient removal from municipal wastewater. Ecol. Eng. 91, 449-458.

598 Leyva-Díaz, J.C., Poyatos, J.M., 2017. Modeling and optimization of membrane 599 bioreactors and moving bed biofilm reactor-membrane bioreactors. Chem. Eng. 600 Technol. 40 (9), 1726-1735.

601 Leyva-Díaz, J.C., Calero-Díaz, G., López-López, C., Martín-Pascual, J., Torres, J.C., 602 Poyatos, J.M., 2017a. Kinetic study of the effect of bisphenol A on the rates of organic 603 matter removal, decay and biomass generation in a membrane bioreactor. Biochem. 604 Eng. J. 128, 45-53.

605 Leyva-Díaz, J.C., Poyatos, J.M., Barghini, P., Gorrasi, S., Fenice, M., 2017b. Kinetic 606 modeling of Shewanella baltica KB30 growth on different substrates through 607 respirometry. Microb. Cell Fact. 16, 189.

608 Liu, Y., Hu, J., Xu, B., He, J., Gao, P., Liu, K., Xue, G., Ognier, S., 2013. Isolation and 609 identification of an iopromide-degrading strain and its application in an $\mathrm{A}^{2} \mathrm{O}$ system. 610 Bioresour. Technol. 134, 36-42.

611 Metcalf, E., 2003. Wastewater Engineering Treatment and Reuse, Mc Graw Hill, United 612 Kingdom.

613 Mojica, E.R.E., Aga, D.S., 2011. Antibiotics pollution in soil and water: potential 614 ecological and human health issues, in: J.O. Nriagu (Ed.), Encyclopedia of 615 Environmental Health, Elsevier, Burlington, pp. 97-110.

616 Park, S., Choi, K., 2008. Hazard assessment of commonly used agricultural antibiotics 617 on aquatic ecosystems. Ecotoxicology 17, 526-538. 
Park, H.O., Oh, S., Bade, R., Shin, W.S., 2010. Application of $\mathrm{A}^{2} \mathrm{O}$ moving-bed biofilm

619 reactors for textile dyeing wastewater treatment. Korean J. Chem. Eng. 27 (3), 893-899.

620 Patiño, Y., Díez, E., Ordóñez, S., 2016. Pre-concentration of nalidixic acid through 621 adsorption-desorption cycles: Adsorbent selection and modeling. Chem. Eng. J. 283, $622 \quad 486-494$.

623 Pollice, A., Laera, G., Cassano, D., Diomede, S., Pinto, A., Lopez, A., Mascolo, G., 624 2012. Removal of nalidixic acid and its degradation products by an integrated MBR625 ozonation system. J. Hazard. Mater. 203-204, 46-52.

626

Servais, P., Passerat, J., 2009. Antimicrobial resistance of fecal bacteria in waters of the

627

Seine river watershed (France). Sci. Total Environ. 408, 365-372.

628

Sirtori, C., Zapata, A., Gernjak, W., Malato, S., Lopez, A., Agüera, A., 2011. Solar 629 photo-Fenton degradation of nalidixic acid in waters and wastewaters of different 630 composition. Analytical assessment by LC-TOF-MS. Water Res. 45, 1736-1744.

631

Tahrani, L., Soufi, L., Mehri, I., Najjari, A., Hassan, A., Loco, J.V., Reyns, T., Cherif,

632 A., Mansour, H.B., 2015. Isolation and characterization of antibiotic-resistant bacteria 633 from pharmaceutical industrial wastewaters. Microb. Pathogenesis 89, 54-61.

634 Vasiliadou, I.A., Molina, R., Martinez, F., Melero, J.A., Stathopoulou, P.M., Tsiamis, 635 G., 2018. Toxicity assessment of pharmaceutical compounds on mixed culture from 636 activated sludge using respirometric technique: The role of microbial community 637 structure. Sci. Total Environ. 630, 809-819.

638 Vining, G.G., 2003. Statistical Methods for Engineers, Duxbury Press, Pacific Grove, 639 CA. 

sulfonamide antibiotics by activated sludge: Experimental assessment using batch data obtained under aerobic conditions. Water Res. 45, 3389-3397.

643

Zhang, X., Zhang, T., Fang, H.P., 2009. Antibiotic resistance genes in water

644

645

646

647

648

649

650

651

652

653

654

655

656

657

658

659

660

661

662

663 environment. Appl. Micobiol. Biotechnol. 82, 397-414.

Zhang, S., Han, B., Gu, J., Wang, C., Wang, P., Ma, Y., Cao, J., He, Z., 2015. Fate of antibiotic resistant cultivable heterotrophic bacteria and antibiotic resistance genes in wastewater treatment processes. Chemosphere 135, 138-145.

\section{Figure captions}

Figure 1. Flowchart of the WWTP of Villapérez (Asturias, Spain) for municipal wastewater treatment.

Figure 2. Degradation rate for carbon source $\left(\mathrm{r}_{\mathrm{su}, \mathrm{H}}\right)(\mathrm{a})$, net heterotrophic biomass growth rate $\left(\mathrm{r}^{\prime}{ }_{\mathrm{x}, \mathrm{H}}\right)(\mathrm{b})$, degradation rate for ammonium source $\left(\mathrm{r}_{\mathrm{su}, \mathrm{A}}\right)(\mathrm{c})$, and net autotrophic biomass growth rate $\left(\mathrm{r}^{\prime}{ }_{\mathrm{x}, \mathrm{A}}\right)(\mathrm{d})$ in absence and presence of nalidixic acid (NAL) for the three operation periods. Data are mean of three replicates and error bars represent standard deviation.

Figure 3. Triplot diagram for redundancy analysis (RDA) of the kinetic parameters (Y, $\mu_{\mathrm{m}}, \mathrm{K}_{\mathrm{S}}$ and $\left.\mathrm{b}\right)$, substrate degradation rate $\left(\mathrm{r}_{\mathrm{su}}\right)$ and net biomass growth rate $\left(\mathrm{r}^{\prime}{ }_{\mathrm{x}}\right)$ in relation to the operation variables HRT, $\mathrm{XVSS}_{\mathrm{VS}}$, T and SRT for heterotrophic biomass in absence of nalidixic acid (NAL) (a) and presence of NAL (b), and for autotrophic 
664 biomass in absence of NAL (c) and presence of NAL (d) within the NIPHO activated

665 sludge reactor.

666

667

668

669

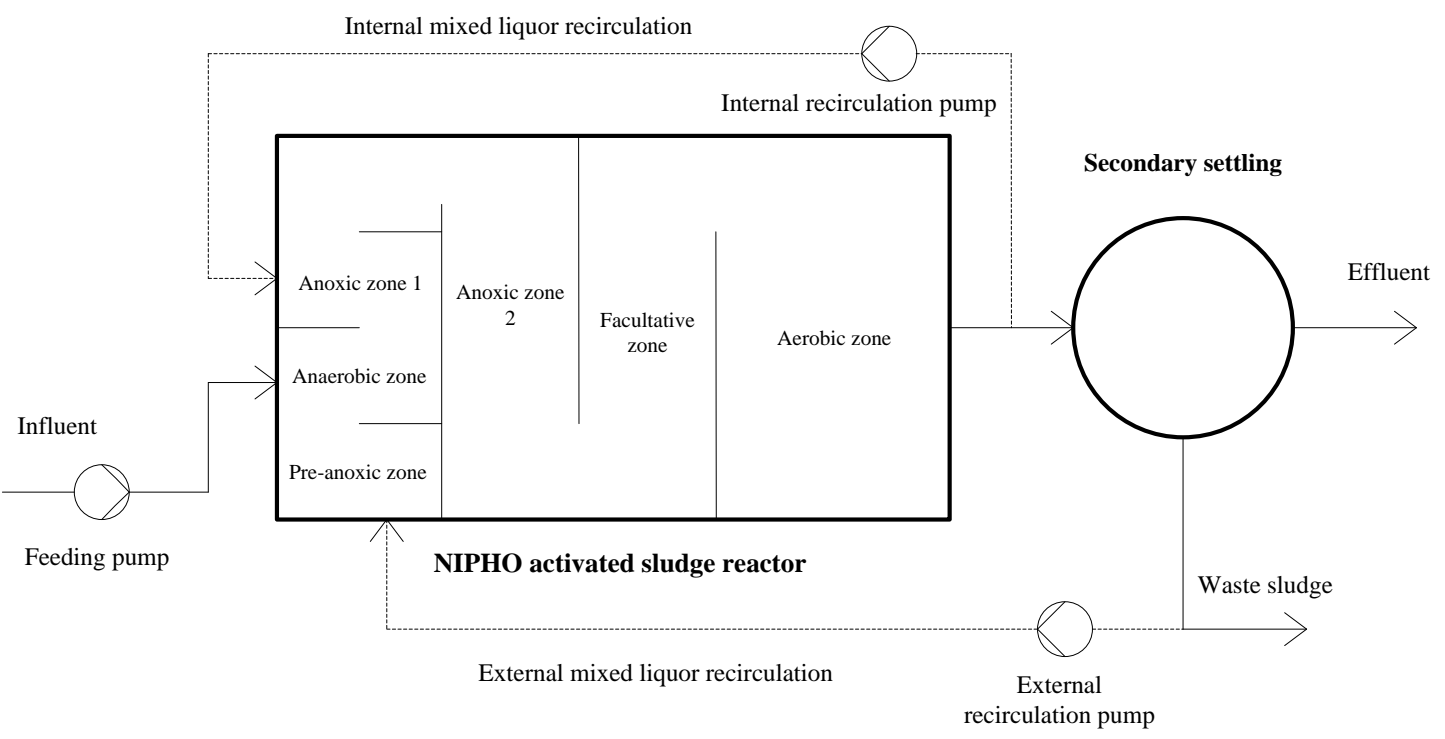

670

671

Figure 1

672

673

674

675

676

677

678

679

680

681 


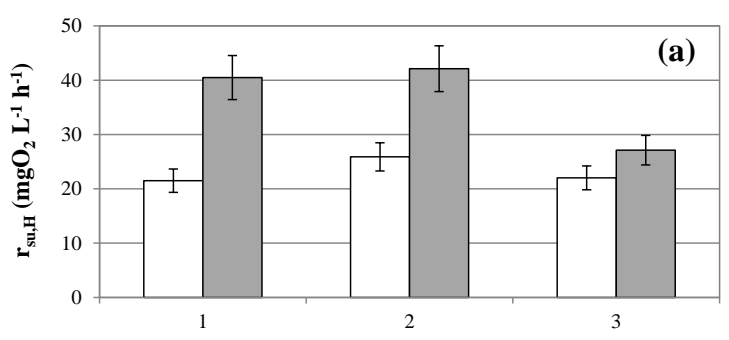

Operation period

$\square$ Absence of NAL $\square$ Presence of NAL

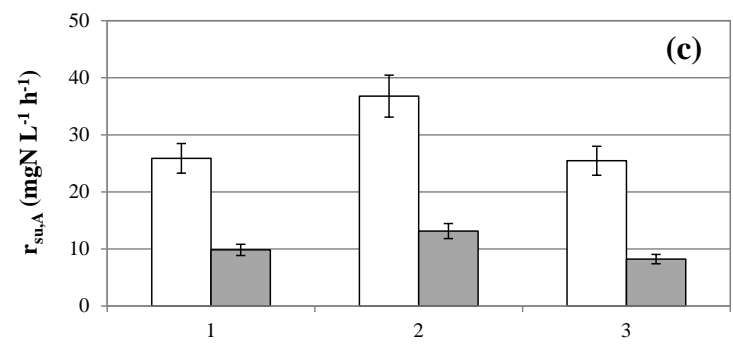

Operation period

682

683

684

685

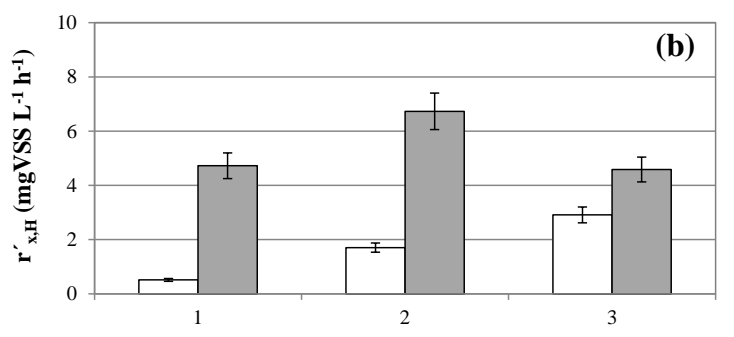

Operation period

$\square$ Absence of NAL $\quad \square$ Presence of NAL

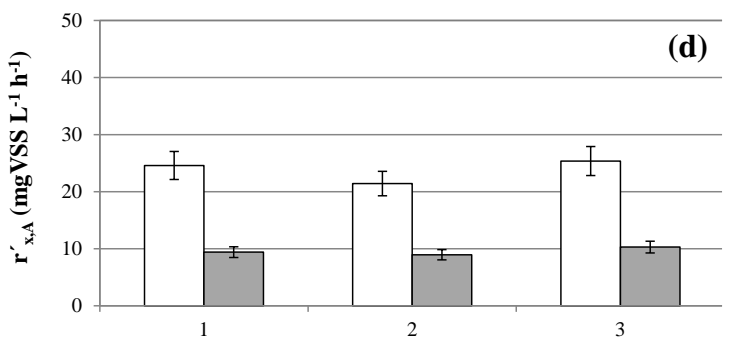

Operation period

Figure 2 

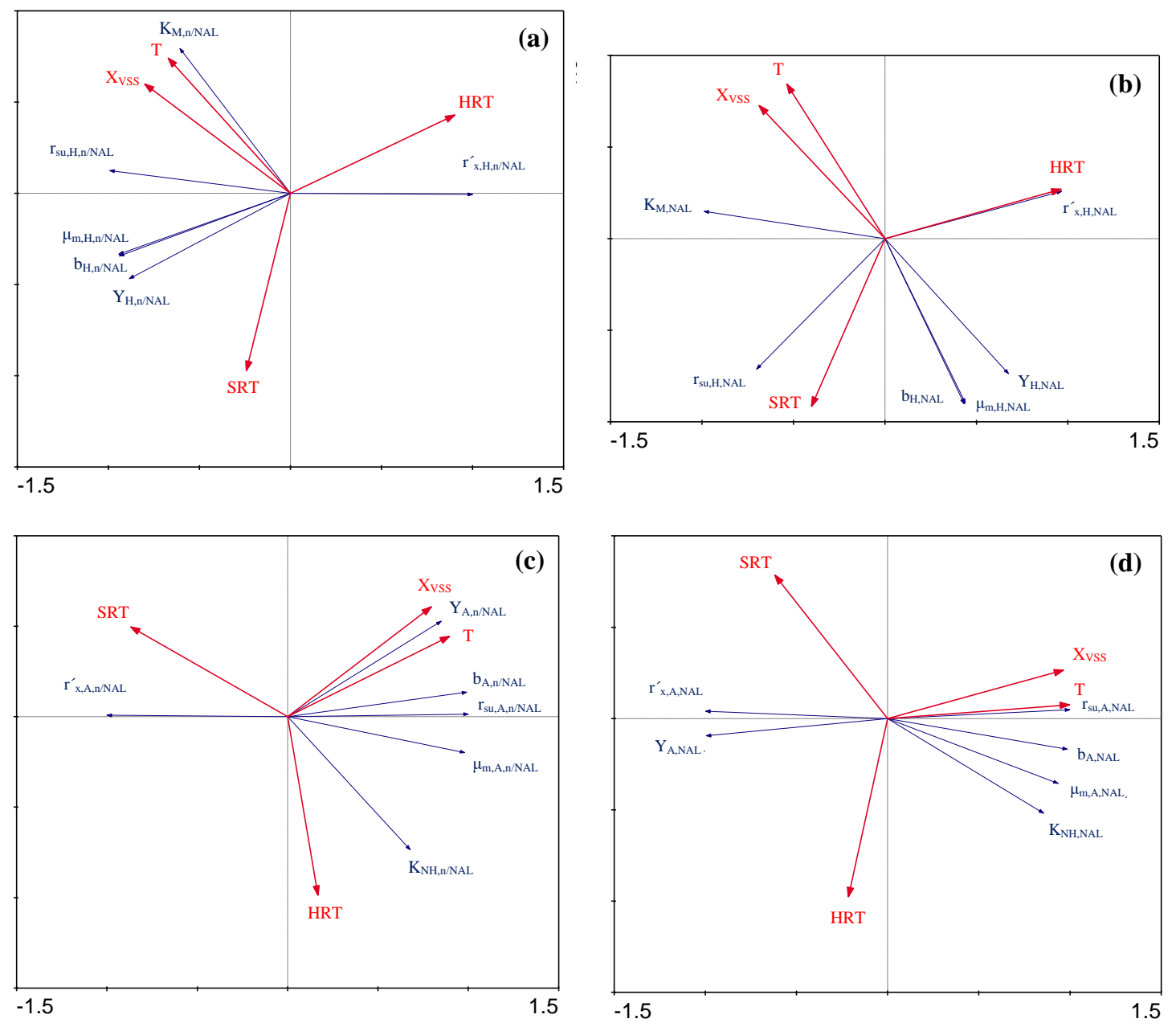

687

688

Figure 3

689

690

691

692

693

694

695

696

697

698

699 
Table 1. Kinetic parameters for heterotrophic and autotrophic biomass in absence and presence of nalidixic acid (NAL) for the three operation periods of the NIPHO activated sludge reactor.

\begin{tabular}{ccccc}
\hline \multirow{2}{*}{ Parameter } & \multicolumn{4}{c}{ Operation period } \\
\cline { 2 - 4 } & $\mathbf{1}$ & $\mathbf{2}$ & $\mathbf{3}$ \\
\hline
\end{tabular}

HETEROTROPHIC KINETICS

\begin{tabular}{|c|c|c|c|}
\hline \multicolumn{4}{|c|}{ Absence of $N A L$} \\
\hline$Y_{H, n / N A L}\left(m g V S S ~ \operatorname{mgCOD}^{-1}\right)$ & $0.4252 \pm 0.0358$ & $0.3596 \pm 0.0388$ & $0.4071 \pm 0.0432$ \\
\hline$\mu_{\mathrm{m}, \mathrm{H}, \mathrm{n} / \mathrm{NAL}}\left(\mathbf{h}^{-1}\right)$ & $0.0060 \pm 0.0007$ & $0.0061 \pm 0.0009$ & $0.0068 \pm 0.0008$ \\
\hline $\mathrm{K}_{\mathrm{M}, \mathrm{n} / \mathrm{NAL}}\left(\mathbf{m g} \mathbf{O}_{2} \mathbf{L}^{-1}\right)$ & $0.1390 \pm 0.0249$ & $1.1513 \pm 0.1342$ & $0.3465 \pm 0.0548$ \\
\hline $\mathbf{b}_{\mathbf{H}, \mathbf{n} / \mathrm{NAL}}\left(\right.$ day $\left.^{-1}\right)$ & $0.1342 \pm 0.0129$ & $0.1106 \pm 0.0098$ & $0.0913 \pm 0.0099$ \\
\hline \multicolumn{4}{|c|}{ Presence of NAL } \\
\hline$Y_{\mathrm{H}, \mathrm{NAL}}\left(\mathrm{mgVSS} \mathrm{mgCOD}^{-1}\right)$ & $0.2828 \pm 0.0111$ & $0.3154 \pm 0.0323$ & $0.3686 \pm 0.0411$ \\
\hline$\mu_{\mathrm{m}, \mathrm{H}, \mathrm{NAL}}\left(\mathbf{h}^{-1}\right)$ & $0.0086 \pm 0.0009$ & $0.0093 \pm 0.0011$ & $0.0080 \pm 0.0009$ \\
\hline $\mathbf{K}_{\mathrm{M}, \mathrm{NAL}}\left(\mathbf{m g O}_{2} \mathbf{L}^{-1}\right)$ & $6.3391 \pm 0.6479$ & $5.3233 \pm 0.3286$ & $1.9073 \pm 0.1986$ \\
\hline $\mathrm{b}_{\mathrm{H}, \mathrm{NAL}}\left(\mathrm{day}^{-1}\right)$ & $0.0854 \pm 0.0058$ & $0.0771 \pm 0.0109$ & $0.0696 \pm 0.0065$ \\
\hline \multicolumn{4}{|c|}{ AUTOTROPHIC KINETICS } \\
\hline \multicolumn{4}{|c|}{ Absence of $N A L$} \\
\hline $\mathrm{Y}_{\mathrm{A}, \mathrm{n} / \mathrm{NAL}}\left(\mathrm{mgVSS} \mathbf{m g N}^{-1}\right)$ & $1.2281 \pm 0.1508$ & $0.7255 \pm 0.0520$ & $1.3434 \pm 0.1226$ \\
\hline$\mu_{m, A, n / N A L}\left(h^{-1}\right)$ & $0.2749 \pm 0.0323$ & $0.2239 \pm 0.0187$ & $0.6614 \pm 0.0630$ \\
\hline $\mathrm{K}_{\mathrm{NH}, \mathrm{n} / \mathrm{NAL}}\left(\mathbf{m g N ~ L}^{-1}\right)$ & $0.8779 \pm 0.0815$ & $0.7298 \pm 0.0892$ & $1.5615 \pm 0.1486$ \\
\hline $\mathbf{b}_{\mathrm{A}, \mathrm{n} / \mathrm{NAL}}\left(\right.$ day $\left.^{-1}\right)$ & $0.0587 \pm 0.0069$ & $0.0816 \pm 0.0086$ & $0.1133 \pm 0.0091$ \\
\hline \multicolumn{4}{|c|}{ Presence of NAL } \\
\hline $\mathbf{Y}_{\mathrm{A}, \mathrm{NAL}}\left(\mathbf{m g V S S} \mathbf{m g N}^{-1}\right)$ & $1.2428 \pm 0.1290$ & $0.8573 \pm 0.0796$ & $1.7017 \pm 0.1611$ \\
\hline$\mu_{\mathrm{m}, \mathrm{A}, \mathrm{NAL}}\left(\mathbf{h}^{-1}\right)$ & $0.1010 \pm 0.0097$ & $0.0912 \pm 0.0081$ & $0.2334 \pm 0.0176$ \\
\hline $\mathrm{K}_{\mathrm{NH}, \mathrm{NAL}}\left(\mathbf{m g N ~ L}^{-1}\right)$ & $0.2128 \pm 0.0161$ & $0.2195 \pm 0.0312$ & $0.3900 \pm 0.0286$ \\
\hline $\mathbf{b}_{\mathrm{A}, \mathrm{NAL}}\left(\mathrm{day}^{-1}\right)$ & $0.0360 \pm 0.0048$ & $0.0569 \pm 0.0059$ & $0.0898 \pm 0.0074$ \\
\hline
\end{tabular}

704

705

706

707

708

709

710

711 
Table 2. Mathematical modeling and optimization of heterotrophic and autotrophic kinetics for the 713 NIPHO activated sludge reactor in absence and presence of nalidixic acid (NAL).

\begin{tabular}{|c|c|c|c|c|}
\hline \multirow{2}{*}{ Fitting parameter } & \multicolumn{2}{|c|}{ Heterotrophic kinetics $(\mathrm{H})$} & \multicolumn{2}{|c|}{ Autotrophic kinetics (A) } \\
\hline & Absence of NAL & Presence of NAL & Absence of NAL & Presence of NAL \\
\hline$\lambda_{1, \mathrm{H} / \mathrm{A}}$ & -0.00377 & 0.05895 & -0.14472 & -0.01785 \\
\hline$\lambda_{2, \mathrm{H} / \mathrm{A}}$ & 0.00002 & 0.00001 & -0.00506 & -0.00715 \\
\hline$\lambda_{3, \mathrm{H} / \mathrm{A}}$ & 0.00181 & 0.00519 & -0.00718 & 0.00517 \\
\hline$\lambda_{4, \mathrm{H} / \mathrm{A}}$ & 0.00001 & -0.00001 & 0.00001 & 0.00001 \\
\hline$\lambda 5, \mathrm{H} / \mathrm{A}$ & 0.02416 & 0.00370 & 0.15822 & 0.15029 \\
\hline $\mathrm{R}^{2}$ & 0.97085 & 0.97482 & 0.99913 & 0.99973 \\
\hline$\gamma_{1, \mathrm{H} / \mathrm{A}}$ & -0.00424 & 0.01690 & -1.92146 & -0.85544 \\
\hline$\gamma_{2, \mathrm{H} / \mathrm{A}}$ & 0.00023 & -0.00199 & 6.42573 & 3.87542 \\
\hline$\gamma_{3, \mathrm{H} / \mathrm{A}}$ & 0.00668 & -0.01356 & 0.78239 & 0.65367 \\
\hline$\gamma_{4, \mathrm{H} / \mathrm{A}}$ & -0.00012 & 0.00133 & -9.01171 & -1.85340 \\
\hline$\gamma_{5, \mathrm{H} / \mathrm{A}}$ & -0.00570 & 0.17993 & -8.33858 & -4.98311 \\
\hline $\mathrm{R}^{2}$ & 0.99700 & 0.99780 & 0.99997 & 0.99990 \\
\hline$\varphi 1, \mathrm{H} / \mathrm{A}$ & 0.31647 & -2.02909 & 0.11956 & 0.05468 \\
\hline$\varphi 2, \mathrm{H} / \mathrm{A}$ & 0.00208 & 0.00900 & -0.00724 & -0.00135 \\
\hline$\varphi_{3, \mathrm{H} / \mathrm{A}}$ & 0.01107 & -0.14500 & 0.01657 & 0.00616 \\
\hline$\varphi 4, \mathrm{H} / \mathrm{A}$ & 0.00002 & -0.00019 & -0.00001 & -0.00001 \\
\hline$\varphi 5, \mathrm{H} / \mathrm{A}$ & -0.31326 & -0.22895 & 0.09714 & 0.01374 \\
\hline $\mathrm{R}^{2}$ & 0.98063 & 0.99871 & 0.99970 & 0.99942 \\
\hline$\alpha_{1, \mathrm{H} / \mathrm{A}}$ & 0.46998 & 0.20145 & -0.39817 & -0.39754 \\
\hline$\alpha_{2, \mathrm{H} / \mathrm{A}}$ & -0.01946 & -0.01063 & 0.56121 & 0.71279 \\
\hline$\alpha_{3, \mathrm{H} / \mathrm{A}}$ & -0.19326 & -0.07797 & 0.23255 & 0.22925 \\
\hline$\alpha_{4, \mathrm{H} / \mathrm{A}}$ & -0.02414 & 0.02511 & -0.14763 & -0.15376 \\
\hline$\alpha_{5, \mathrm{H} / \mathrm{A}}$ & 1.64494 & 0.91491 & -0.64990 & -0.85104 \\
\hline $\mathrm{R}^{2}$ & 0.99975 & 0.99973 & 0.99982 & 0.99927 \\
\hline \multicolumn{5}{|c|}{ Optimum operational conditions } \\
\hline HRT (h) & 3.8 & 2.8 & 3.8 & 3.8 \\
\hline $\mathrm{XVSS}_{\mathrm{VS}}\left(\mathrm{mgVSS} \mathrm{L}^{-1}\right)$ & 1,566 & 1,566 & 125 & 125 \\
\hline $\mathrm{T}\left({ }^{\circ} \mathrm{C}\right)$ & 12.6 & 14.8 & 12.6 & 12.6 \\
\hline SRT (day) & 12.6 & 11.0 & 12.6 & 12.6 \\
\hline \multicolumn{5}{|c|}{ Optimum response } \\
\hline $\mathrm{Y}_{\mathrm{H}}\left(\mathrm{mgVSS} \mathrm{mgCOD}^{-1}\right)$ & 0.3291 & 0.2150 & - & - \\
\hline$\mu_{\mathrm{m}, \mathrm{H}}\left(\mathrm{h}^{-1}\right)$ & 0.0051 & 0.0088 & - & - \\
\hline $\mathrm{K}_{\mathrm{M}}\left(\mathrm{mgO}_{2} \mathrm{~L}^{-1}\right)$ & 0.5272 & 5.7529 & - & - \\
\hline $\mathrm{b}_{\mathrm{H}}\left(\mathrm{day}^{-1}\right)$ & 0.0606 & 0.0773 & - & - \\
\hline $\mathrm{r}_{\mathrm{su}, \mathrm{H}}\left(\mathrm{mgO}_{2} \mathrm{~L}^{-1} \mathrm{~h}^{-1}\right)$ & 23.96 & 54.52 & - & - \\
\hline$r^{\prime}{ }_{x, H}\left(m g V S S L^{-1} h^{-1}\right)$ & 3.93 & 6.68 & - & - \\
\hline $\mathrm{Y}_{\mathrm{A}}\left(\mathrm{mgVSS} \mathrm{mgN}^{-1}\right)$ & - & - & 0.8013 & 0.9342 \\
\hline$\mu_{\mathrm{m}, \mathrm{A}}\left(\mathrm{h}^{-1}\right)$ & - & - & 0.4835 & 0.1676 \\
\hline $\mathrm{K}_{\mathrm{NH}}\left(\mathrm{mgN} \mathrm{L}^{-1}\right)$ & - & - & 0.7863 & 0.2174 \\
\hline $\mathrm{b}_{\mathrm{A}}\left(\mathrm{day}^{-1}\right)$ & - & - & 0.0834 & 0.0656 \\
\hline $\mathrm{r}_{\mathrm{su}, \mathrm{A}}\left(\mathrm{mgN} \mathrm{L}^{-1} \mathrm{~h}^{-1}\right)$ & - & - & 69.21 & 22.02 \\
\hline $\mathrm{r}^{\prime}{ }_{\mathrm{x}, \mathrm{A}}\left(\mathrm{mgVSS} \mathrm{L} \mathrm{L}^{-1} \mathrm{~h}^{-1}\right)$ & - & - & 55.02 & 20.23 \\
\hline
\end{tabular}

